\title{
Research on the Influence of Urbanization on Income Gap between Urban and Rural Areas
}

\section{-Based on Income Source}

\author{
Xiaomei Pu${ }^{1}$, Yumei Zhu ${ }^{2}$ \\ ${ }^{1}$ Research Center of Sichuan Old Revolutionary Areas Development, Sichuan University of Arts and Science, Dazhou, China \\ ${ }^{2}$ School of Foreign Languages, Sichuan University of Arts and Science, Dazhou, China \\ Email: 47872614@qq.com
}

How to cite this paper: $\mathrm{Pu}, \mathrm{X} . \mathrm{M}$. and $\mathrm{Zhu}$ Y.M. (2018) Research on the Influence of Urbanization on Income Gap between Urban and Rural Areas. Open Journal of Social Sciences, 6, 132-141.

https://doi.org/10.4236/jss.2018.66013

Received: May 22, 2018

Accepted: June 11, 2018

Published: June 14, 2018

Copyright $\odot 2018$ by authors and Scientific Research Publishing Inc. This work is licensed under the Creative Commons Attribution International License (CC BY 4.0).

http://creativecommons.org/licenses/by/4.0/

\begin{abstract}
According to China's panel data between 2002 and 2016, the present thesis first analyzed the overall effects and time effects of urbanization on wage disparity, net operating income disparity, net property income gap, and net transferred income disparity between urban and rural residents, and then analyzed the overall effects and time effects of each income disparity on the total income gap between urban and rural residents. In general, the impact of urbanization on urban-rural income disparity was studied from the perspective of income sources. The results show that urbanization bridges the income gap between urban and rural areas, with an inverted U-shaped structure which increases first and then narrows, from the income sources perspective. So, the targeted and operational policy recommendations are proposed.
\end{abstract}

\section{Keywords}

Urbanization, Income Gap between Urban and Rural Areas, Source of Income

\section{Introduction}

It's important to study the relationship between urbanization and excessive rural-urban income gap for the reason that one is playing a significant role on modernization and the other is a huge obstacle for building a moderately prosperous society in an all-round way. The research on the impact of urbanization on urban-rural income gap at home and abroad mainly includes two major aspects. The first is the total impact of urbanization on urban-rural income gap. Research in this area has mainly formed three distinct perspectives. Fujita Masahisa and Krugman [1] believe that urbanization has a significant expansion effect 
on the urban-rural income gap. Lin Yifu, Liu Mingxing (2003) [2], and Yan Shaomin (2016) [3] came to the same conclusion after adopted provincial panel data from China respectively and the city-level panel data in Henan Province. At the same time, Lewis (1954) [4], Todaro (1969) [5] and others consider that the urban-rural income gap has gradually narrowed with the development of urbanization, which is the same as the view of Lu Ming, one of the Chinese scholar, and Chen Zhao (2004) [6], Yang Guo'an, Xu Yong (2011) [7] through empirical analysis. Meanwhile, Kuznets (1955) and Robinson thought that with the advancement of urbanization, the urban-rural income gap expanded first and then gradually narrowed. Zhou Yunbo (2009) [8] also held the same view. Second, researches on the impact of urbanization on various incomes between urban and rural areas were conducted. Wang Min and Cao Runlin (2015) [9] held the view that with the progress of urbanization, the income gap between urban and rural residents' property continues to expand. However, Fang Na and Zhang Kaihua [10] said that there is a long-term and stable positive relationship between urbanization and wage income of farmers for the long run.

The above researches have studied the impact of urbanization on the income gap between urban and rural areas from an overall and local perspective, without integrating the overall and local systems to systematically investigate the impact of urbanization on urban-rural income gaps. In terms of the overall impact of urbanization on the urban-rural income gap, it is difficult to put forward specific recommendations if the different effects of urbanization on various income disparities between urban and rural residents are ignored. It is also difficult to make supportive and practical suggestions, without fully reflecting the impact of urbanization on it, as the terms of researches on the impact of urbanization on the various components of it. Therefore, this study attempts to overcome these shortcomings by using China's panel data from 2002 to 2016 to analyze from the overall and time effect of urbanization for the urban and rural residents on wage income disparity, operating net income gap, property net income gap, and transferring of net income gap, to the overall and time effect of various income gap between urban and rural areas for the total of it, and finally put forward targeted and operational suggestions.

\section{The Selection of Variables and Data}

To study the impact of urbanization on the urban-rural income gap from the perspective of income sources, it is necessary to refer the following two indicators: First, the urban-rural income gap indicators, including the total urban-rural income gap (ig), urban and rural residents wage income gap (wig), operating net income gap (oig), net property income gap (pig), transfer of net income gap (tig). The Gini coefficient, Theil index, Lorenz curve, etc. are used to measure the income gap between urban and rural areas. This paper uses the most common urban-rural income ratio to measure the income gap between urban and rural areas. Before calculation, the urban-rural consumer price index 
is assumed as $2002=100$. These income disparity indicators are calculated by using the ratio of urban residents' income and rural residents' income. And they were all subsidized by the urban-rural consumer price index $(2002=100)$ before calculation. The closer the income gap index value is to 1 , the smaller the gap is. The value is greater, the income is greater too, and vice versa. The second is the urbanization index (ui). Due to urban and rural residents' wage income, operating income, property income, and transferring income are all based on the resident population, the article uses the ratio of permanent residents in town to maintain the consistency of statistical criteria. The data on income sources of urban and rural residents in many provinces before 2002 were missing. Therefore, all the data selected in this paper are panel data composed of 30 mainland provinces, municipalities, and autonomous regions (there are some partly missing data in Tibet) between 2002 and 2016. All data were from China Statistical Yearbook (2003-2017) by software stata 12.0 .

\section{Empirical Analysis}

\subsection{The Impact of Urbanization on the Income Source of Urban and Rural Residents}

In this section, we refer to the research results of Ouyang Jinqiong, Wang Yapeng (2014) [11], Wu Peng, Li Junqiang, and Jing Zhuang zhuang (2016) [12], and improve the model they constructed to four regression models to explore the impact of urbanization on wage income disparity between urban and rural residents, net income disparity, net property income disparity, and net income disparity. In the following formula, $i, t, \alpha$, and $\mu$ represents province, year, intercept and residual. The results of the analysis are shown in Table 1 and Table 2.

$$
\begin{gathered}
w_{i g_{i t}}=\alpha+\beta . u r+\mu_{i t} \\
\operatorname{oig}_{i t}=\alpha+\beta . u r+\mu_{i t} \\
\operatorname{pig}_{i t}=\alpha+\beta . u r+\mu_{i t} \\
\operatorname{tig}_{i t}=\alpha+\beta . u r+\mu_{i t}
\end{gathered}
$$

\subsubsection{Analysis of the Influence of Urbanization on Wage Income Difference between Urban and Rural Residents}

Judging from the overall effect, the advancement of urbanization has been conducive to the reduction of the wage income gap between urban and rural areas in recent years. Every degree of urbanization has increased by one percent which can lead to the wage income gap between urban and rural areas to reduce by 22.853 percent. The main reason for this situation is due to the rapid development of urbanization in recent years. A large number of rural surplus labors have been transferred to cities and their wage income has continued to increase, thus narrowed the income gap between urban and rural residents. From the time effect point of view, the coefficients are not significant, except for 2002-2009. The coefficient for 2010-2016 is negative which indicates that urbanization has narrowed the wage income gap between urban and rural areas, and constantly 
Table 1. The overall effect of urbanization on income sources of urban and rural residents.

\begin{tabular}{ccccc}
\hline variable & wig & oig & pig & tig \\
\hline ur & $-22.853^{\star * *}$ & $3.034^{\star * *}$ & 2.356 & $-43.912^{\star * \star}$ \\
& $(1.962)$ & $(0.148)$ & $(3.766)$ & $(3.355)$ \\
\hline
\end{tabular}

Note: 1$)^{*},{ }^{* *}$, and ${ }^{* *}$ are significant at the $10 \%, 5 \%$, and $1 \%$ significance levels, respectively. 2) The value in parentheses is the standard deviation.

Table 2. Time effect of urbanization on sources of income of urban and rural residents.

\begin{tabular}{|c|c|c|c|c|c|c|c|c|c|}
\hline & wig & oig & pig & Tig & & wig & oig & pig & Tig \\
\hline 2002 & $\begin{array}{l}-2.519 \\
(4.100)\end{array}$ & $\begin{array}{c}1.071^{* * *} \\
(0.252)\end{array}$ & $\begin{array}{l}-7.025^{*} \\
(4.155)\end{array}$ & $\begin{array}{c}-8.121^{\star * *} \\
(3.727)\end{array}$ & 2010 & $\begin{array}{c}-4.102^{* *} \\
(0.751)\end{array}$ & $\begin{array}{c}1.373^{* * *} \\
(0.052)\end{array}$ & $\begin{array}{c}-4.799^{* *} \\
(2.252)\end{array}$ & $\begin{array}{c}-18.201^{* * *} \\
(1.237)\end{array}$ \\
\hline 2003 & $\begin{array}{l}-2.173 \\
(0.629)\end{array}$ & $\begin{array}{c}1.089 \\
(0.046)\end{array}$ & $\begin{array}{c}-5.984^{* * *} \\
(2.213)\end{array}$ & $\begin{array}{l}-7.247 \\
(1.179)\end{array}$ & 2011 & $\begin{array}{c}-4.835^{\star * *} \\
(0.781)\end{array}$ & $\begin{array}{c}1.425^{\star \star *} \\
(0.054)\end{array}$ & $\begin{array}{c}-4.144^{*} \\
(2.262)\end{array}$ & $\begin{array}{c}-18.829^{\star * *} \\
(1.252)\end{array}$ \\
\hline 2004 & $\begin{array}{l}-1.845 \\
(0.635)\end{array}$ & $\begin{array}{c}1.101 \\
(0.046)\end{array}$ & $\begin{array}{c}-5.553^{* *} \\
(2.215)\end{array}$ & $\begin{array}{c}-11.267^{* * *} \\
(1.181)\end{array}$ & 2012 & $\begin{array}{c}-5.092^{* * *} \\
(0.814)\end{array}$ & $\begin{array}{l}1.461^{\star * *} \\
(0.056)\end{array}$ & $\begin{array}{c}-4.272^{*} \\
(2.274)\end{array}$ & $\begin{array}{c}-18.875^{\star * *} \\
(1.269)\end{array}$ \\
\hline 2005 & $\begin{array}{l}-2.649 \\
(0.650)\end{array}$ & $\begin{array}{l}1.187^{\star *} \\
(0.047)\end{array}$ & $\begin{array}{c}-5.461^{* *} \\
(2.219)\end{array}$ & $\begin{array}{c}-11.16^{* *} \\
(1.188)\end{array}$ & 2013 & $\begin{array}{c}-5.587^{* * *} \\
(0.841)\end{array}$ & $\begin{array}{c}1.529^{* * *} \\
(0.057)\end{array}$ & $\begin{array}{l}-1.945 \\
(2.284)\end{array}$ & $\begin{array}{c}-19.619^{* * *} \\
(1.284)\end{array}$ \\
\hline 2006 & $\begin{array}{l}-2.844 \\
(0.662)\end{array}$ & $\begin{array}{c}1.224^{\star * *} \\
(0.047)\end{array}$ & $\begin{array}{c}-5.254^{* *} \\
(2.222)\end{array}$ & $\begin{array}{c}-13.432^{\star * *} \\
(1.194)\end{array}$ & 2014 & $\begin{array}{c}-5.879^{\star * *} \\
(0.870)\end{array}$ & $\begin{array}{c}1.499^{* * *} \\
(0.059)\end{array}$ & $\begin{array}{l}4.892^{\star *} \\
(2.295)\end{array}$ & $\begin{array}{c}-22.070^{\star * *} \\
(1.299)\end{array}$ \\
\hline 2007 & $\begin{array}{l}-2.945 \\
(0.679)\end{array}$ & $\begin{array}{c}1.202^{* * *} \\
(0.048)\end{array}$ & $\begin{array}{c}-4.772^{\star *} \\
(2.228)\end{array}$ & $\begin{array}{c}-15.152^{\star * *} \\
(1.201)\end{array}$ & 2015 & $\begin{array}{c}-5.891^{\star * *} \\
(0.902)\end{array}$ & $\begin{array}{c}1.457^{* * *} \\
(0.060)\end{array}$ & $\begin{array}{l}4.060^{*} \\
(2.308)\end{array}$ & $\begin{array}{c}-21.234^{* * *} \\
(1.318)\end{array}$ \\
\hline 2008 & $\begin{array}{l}-3.551 \\
(0.697)\end{array}$ & $\begin{array}{c}1.353^{\star * *} \\
(0.049)\end{array}$ & $\begin{array}{c}-4.932^{* *} \\
(2.234)\end{array}$ & $\begin{array}{c}-16.976^{* * *} \\
(1.210)\end{array}$ & 2016 & $\begin{array}{c}-5.980^{* * *} \\
(0.937)\end{array}$ & $\begin{array}{c}1.465^{\star * *} \\
(0.625)\end{array}$ & $\begin{array}{l}4.369^{*} \\
(2.322)\end{array}$ & $\begin{array}{c}-21.562^{* * *} \\
(1.338)\end{array}$ \\
\hline 2009 & $\begin{array}{l}-3.587 \\
(0.715)\end{array}$ & $\begin{array}{c}1.389^{* * *} \\
(0.050)\end{array}$ & $\begin{array}{c}-4.922^{* *} \\
(2.240)\end{array}$ & $\begin{array}{c}-18.188^{\star * *} \\
(1.219)\end{array}$ & & & & & \\
\hline
\end{tabular}

Note: 1$)^{*},{ }^{* *}$, and ${ }^{* *}$ are significant at the $10 \%, 5 \%$, and $1 \%$ significance levels, respectively. 2) The value in parentheses is the standard deviation. 3) $-2.519,1.071,-7.025,-8.121$ are the coefficients of 2002, and other coefficients are the coefficients of each year added to this.

continues. This fully proves that the problem of unfair and unreasonable wage treatment for migrant workers has been solved with the advancement of urbanization in recent years. Meanwhile, the intensified shortage of migrant workers and professional skills training has greatly increased the wage income of these migrant workers.

\subsubsection{Analysis of the Influence of Urbanization on Urban and Rural Residents Operating Net Income Gap}

Judging from the overall effect, the urbanization in recent years has increased the net income gap between urban and rural areas. Every degree of urbanization has increased by one percent which can lead to the net income gap between urban and rural areas to increase by 3.034 percent. This is mainly because that the skilled, young and strong labor forces have been transferred to cities and towns, which results to the overall low quality of rural labor, low degree of agricultural modernization, low quality of agricultural products, not so high price and diffi- 
culties in increasing the net income for farmers. From the point of view of time effect, with the exception of the 2003 and 2004 coefficients, the remaining years are significant. The coefficients are positive to indicate and prove that the development of urbanization has widened the net income gap between urban and rural operations, with inverted $U$-shaped structure which increases first and then narrow, and also reflects the process of rural labor from working in cities to returning home to start a business in recent years.

\subsubsection{Analysis of the Influence of Urbanization on Urban and Rural Residents Net Property Income Gap}

Since the statistical indicators for the net income of resident assets were inconsistent around 2013, the overall effect shows that there is no correlation between urbanization and the net income gap between urban and rural property. However, judging from the time effect, except for the coefficient in 2013 that is not significant, the remaining years are significant. The coefficients for 2002-2012 are negative, indicating that urbanization narrows the gap between urban and rural property net income. And the coefficient for 2014-2016 is positive, which shows that urbanization has expanded the net income gap between urban and rural assets. This is mainly because net income of urban and rural residents in 2013 increased the self-owned housing computed net rental, while the self-owned housing computed net rental of urban residents is obviously higher than that of rural residents.

\subsubsection{Analysis of the Influence of Urbanization on Urban and Rural Residents' Transfer of Net Income Gap}

Judging from the overall effect, the urbanization has narrowed the net income gap between urban and rural areas. Every degree of urbanization increases by one percent, and the net income gap between urban and rural areas will decrease by 43.912 percent. This is mainly due to the fact that the central government has further intensified its efforts to transfer payments to rural areas with the promotion of a new type of urbanization centered on people. From the perspective of time effect, all other years are significant except for the coefficient in 2003. The coefficients are negative, indicating that urbanization has narrowed the net income gap between urban and rural areas, and this shrinking effect is showing an increasing trend which shows that the central government has succeeded in the game with local governments, and the rural bias policy has achieved initial results in recent years.

\subsection{Analysis of the Impact of Various Income Sources of Urban and Rural Residents on Income Gap between It}

In order to thoroughly analyze the impact of various income sources on the urban-rural income gap, the following equations are established. The results of the analysis are shown in Table 3 and Table 4.

$$
i g_{i t}=\alpha+\beta_{1} \cdot w i g+\beta_{2} \cdot o i g+\beta_{3} \cdot p i g+\beta_{4} \cdot t i g+\mu_{i t}
$$


Table 3. The overall effect of urban-rural income gap sources.

\begin{tabular}{ccccc}
\hline ig & Coef. & Std. Err. & $\mathbf{Z}$ & $\mathbf{P}>|\mathbf{z}|$ \\
\hline wig & 0.027 & 0.005 & 6.01 & 0.000 \\
oig & -0.071 & 0.051 & -1.39 & 0.164 \\
pig & -0.006 & 0.001 & -4.72 & 0.000 \\
tig & 0.007 & 0.002 & 3.08 & 0.002 \\
\hline
\end{tabular}

Note: 1$)^{*}, * *$, and ${ }^{* * *}$ are significant at the $10 \%, 5 \%$, and $1 \%$ significance levels, respectively. 2 ) The value in parentheses is the standard deviation.

Table 4. The time effect of sources of urban-rural income gap.

\begin{tabular}{|c|c|c|c|c|c|c|c|c|c|}
\hline & wig & oig & pig & Tig & & wig & oig & pig & Tig \\
\hline 2002 & $\begin{array}{c}0.019^{* * *} \\
(0.004)\end{array}$ & $\begin{array}{c}-0.116^{\star *} \\
(0.053)\end{array}$ & $\begin{array}{l}-0.001 \\
(0.001)\end{array}$ & $\begin{array}{c}0.009^{* * *} \\
(0.002)\end{array}$ & 2010 & $\begin{array}{c}0.387^{* * *} \\
(0.063)\end{array}$ & $\begin{array}{c}0.252^{* * *} \\
(0.112)\end{array}$ & $\begin{array}{c}0.367^{* * *} \\
(0.060)\end{array}$ & $\begin{array}{c}0.377^{* * *} \\
(0.061)\end{array}$ \\
\hline 2003 & $\begin{array}{l}0.126^{\star *} \\
(0.054)\end{array}$ & $\begin{array}{c}-0.009^{* *} \\
(0.103)\end{array}$ & $\begin{array}{l}0.106^{\star *} \\
(0.051)\end{array}$ & $\begin{array}{l}0.116^{\star *} \\
(0.052)\end{array}$ & 2011 & $\begin{array}{c}0.320^{* * *} \\
(0.066)\end{array}$ & $\begin{array}{c}0.185^{* * *} \\
(0.115)\end{array}$ & $\begin{array}{c}0.300^{\star * *} \\
(0.063)\end{array}$ & $\begin{array}{c}0.310^{* * *} \\
(0.064)\end{array}$ \\
\hline 2004 & $\begin{array}{c}0.150^{* * *} \\
(0.054)\end{array}$ & $\begin{array}{c}0.015^{* * *} \\
(0.103)\end{array}$ & $\begin{array}{c}0.130^{* * *} \\
(0.051)\end{array}$ & $\begin{array}{c}0.140^{* * *} \\
(0.052)\end{array}$ & 2012 & $\begin{array}{c}0.298^{* * *} \\
(0.067)\end{array}$ & $\begin{array}{c}0.163^{\star * *} \\
(0.116)\end{array}$ & $\begin{array}{c}0.278^{* * *} \\
(0.064)\end{array}$ & $\begin{array}{c}0.288^{* * *} \\
(0.065)\end{array}$ \\
\hline 2005 & $\begin{array}{c}0.240^{\star * *} \\
(0.055)\end{array}$ & $\begin{array}{c}0.105^{\star * *} \\
(0.104)\end{array}$ & $\begin{array}{c}0.220^{* * *} \\
(0.052)\end{array}$ & $\begin{array}{c}0.230^{\star * \star} \\
(0.053)\end{array}$ & 2013 & $\begin{array}{c}0.220^{* * *} \\
(0.070)\end{array}$ & $\begin{array}{c}0.085^{\star * *} \\
(0.119)\end{array}$ & $\begin{array}{c}0.200^{* * *} \\
(0.067)\end{array}$ & $\begin{array}{c}0.210^{* * *} \\
(0.068)\end{array}$ \\
\hline 2006 & $\begin{array}{c}0.374^{* * *} \\
(0.056)\end{array}$ & $\begin{array}{c}0.239^{* * *} \\
(0.105)\end{array}$ & $\begin{array}{c}0.354^{* * *} \\
(0.053)\end{array}$ & $\begin{array}{c}0.364^{* * *} \\
(0.054)\end{array}$ & 2014 & $\begin{array}{c}0.007 \\
(0.072)\end{array}$ & $\begin{array}{l}-0.065 \\
(0.121)\end{array}$ & $\begin{array}{c}0.050 \\
(0.069)\end{array}$ & $\begin{array}{c}0.060 \\
(0.070)\end{array}$ \\
\hline 2007 & $\begin{array}{c}0.429^{* * *} \\
(0.057)\end{array}$ & $\begin{array}{c}0.294^{* * *} \\
(0.106)\end{array}$ & $\begin{array}{c}0.409^{* * *} \\
(0.054)\end{array}$ & $\begin{array}{c}0.419^{* * *} \\
(0.055)\end{array}$ & 2015 & $\begin{array}{c}0.047 \\
(0.071)\end{array}$ & $\begin{array}{l}-0.088 \\
(0.120)\end{array}$ & $\begin{array}{c}0.027 \\
(0.068)\end{array}$ & $\begin{array}{c}0.037 \\
(0.069)\end{array}$ \\
\hline 2008 & $\begin{array}{c}0.424^{\star * \star} \\
(0.057)\end{array}$ & $\begin{array}{c}0.289^{* * *} \\
(0.106)\end{array}$ & $\begin{array}{c}0.404^{* * *} \\
(0.054)\end{array}$ & $\begin{array}{c}0.414^{* * *} \\
(0.055)\end{array}$ & 2016 & $\begin{array}{c}0.044 \\
(0.072)\end{array}$ & $\begin{array}{l}-0.091 \\
(0.121)\end{array}$ & $\begin{array}{c}0.024 \\
(0.069)\end{array}$ & $\begin{array}{c}0.034 \\
(0.070)\end{array}$ \\
\hline 2009 & $\begin{array}{c}0.477^{* * *} \\
(0.063)\end{array}$ & $\begin{array}{c}0.342^{* * *} \\
(0.112)\end{array}$ & $\begin{array}{c}0.457^{\star * *} \\
(0.060)\end{array}$ & $\begin{array}{c}0.467^{\star * *} \\
(0.061)\end{array}$ & & & & & \\
\hline
\end{tabular}

Note: 1$)^{*},{ }^{* *}$, and ${ }^{* * *}$ are significant at the $10 \%, 5 \%$, and $1 \%$ significance levels, respectively; 2 ) The value in parentheses is the standard deviation; 3 ) $-2.519,1.071,-7.025,-8.121$ are the coefficients of 2002 , and other coefficients are the coefficients of each year added to this.

\subsubsection{Analysis of the Impact of Wage Income on Income Gap between Urban and Rural Areas}

On the whole, the wage income gap between urban and rural areas is the most important cause of the income gap between urban and rural areas. When the gap between urban and rural wage income increases by one percentage point, the urban-rural income gap will increase by 0.027 percentage points, which is significant at the $1 \%$ level of significance, and consistent with the research findings of Zeng Guo'an, Hu Jingjing [13], Zuo Yihe [14] and others. This is mainly due to the following reasons: First, wage income has been the main income of urban residents, and its proportion has been more than $55 \%$. At the same time, wage income is also an important part of the income of rural residents in which annual average value of the ratio is $34 \%$. Second, the wage income gap between urban and rural residents is large, and annual average value of the ratio is 6.09, which is 2.27 times of the urban-rural income gap. From the perspective of time 
effect, the impact of wage income in urban and rural areas on the income gap between urban and rural areas shows an "inverted U-shaped" structure that increases first and then decreases. This is mainly due to the following reasons: First, the proportion of wage income in disposable income of urban residents has generally risen first and then declined, from $75 \%$ in 2002 to $76 \%$ in 2004 , and then declined to $61 \%$ in 2016; Second, the proportion of wage income in disposable income of rural residents generally shows a change track that increases first, then decreases, and then increases again; Third, the wage income gap between urban and rural residents generally expands first and then shrinks.

\subsubsection{Analysis of the Impact of Operating Net Income on Income Gap between Urban and Rural}

On the whole, the net income gap between urban and rural areas will cause the urban-rural gap to shrink, but it is not significant. From the perspective of time effect, the net income gap between urban and rural areas in 2002-2003 shows a shrinking effect on the urban-rural income gap. Then, by 2004, this narrowing effect began to become an expansion effect which did not change back to shrinkage until 2014, but not obvious. This is mainly due to the following two reasons: First, in the process of urbanization, the dominant position of net income in rural residents' income has been gradually replaced by wage income, and its proportion in disposable income has declined linearly from $60 \%$ in 2002 to $38 \%$ in 2016. Second, the proportion of household income from urban households continued to increase, with the proportion rising from $4 \%$ in 2002 to $11 \%$ in 2016. Third, the net income gap between urban and rural operations generally shows a narrowing trend.

\subsubsection{Analysis of the Impact of Net Property Income on Income Gap between Urban and Rural}

Overall, the income gap between urban and rural residents will cause a narrowing gap between urban and rural areas, but the proportion will be relatively small. The urban-rural property income gap increase by one percent that the urban-rural income gap will shrink by 0.006 percent, which is significant at $1 \%$ and is consistent with the research findings of Li Qiyun and Chi Cheng [15]. This is mainly due to the fact that the proportion of net property income to residents' disposable income has been relatively small. The annual average value of net property income from urban and rural residents in 2002-2016 was only $4 \%$. From the time effect point of view, except for the insignificant reduction effect in 2002, the rest of the years are enlarged, and this expansion effect shows an "inverted U-shaped" structure that increases first and then decreases. This is mainly due to the following reasons: First, the proportion of net property income in disposable income of urban residents has been increasing, from $1 \%$ in 2002 to $10 \%$ in 2016; second, the proportion of net property income in disposable income of rural residents shows a trajectory of that first increases, and then decreases, and finally increases. Third, the net income gap between urban and rural residents shows a trend of increasing first, then shrinking and then increasing again. 


\subsubsection{Analysis of the Impact of Transfer of Net Income on Income Gap between Urban and Rural}

All along, the distribution of net income among urban and rural residents has been the most uneven. From 2002 to 2016, the annual average value of the ratio was 15.39 , which were far above than the wage income gap. However, due to its relatively small proportion of urban and rural residents' income, the average annual value of net property income in urban and rural residents' during 2002-2016 accounted for 17\%. Therefore, as a whole, the urban-rural transfer net income gap will cause the urban-rural disparity to widen, but the proportion is relatively small. The net income gap between urban and rural areas increases per $100 \%$ that the urban-rural income gap will increase by $0.007 \%$, which is significant at the $1 \%$ level of significance. Judging from the time effect, the transfer net income gap between urban and rural areas in 2002-2016 has always been an increase effect in the urban-rural income gap, and this increase has generally shown an "inverted U-shaped" structure that increases first and then decreases. This is mainly due to the following reasons: First, the proportion of net income transferred to disposable income of rural residents has shown an overall upward trend from $4 \%$ to $19 \%$; Second, the proportion of net transfer income in the disposable income of urban residents shows a trend of decreasing to increasing and then decreasing, finally increasing. Third, the transfer net income gap between urban and rural residents shows a tendency of gradually decreasing, from 20.40 in 2002 to 2.54 in 2016.

From the analysis above, wage difference is still the main reason of income gap, while net income transferring might enlarge the gap, less significantly however; in terms of net operating income gap and net property income gap, they may shorten the gap, but just slightly.

\section{Conclusions}

This paper uses the provincial panel data from 2002-2016 in China to empirically analyze the impact of urbanization on various urban-rural income disparities and urban-rural income gaps. The study finds that: 1) Overall, urbanization is conducive to shrink wage income disparity between urban and rural areas, and then will further reduce the urban-rural income gap, which is quite obvious. Therefore, this aspect should be considered first when formulating policies. From the perspective of time, this shrinking effect shows an "inverted U-shaped" structure that increases first and then shrinks; 2) From the overall perspective, the advancement of urbanization will increase the operating net income gap between urban and rural operations, while which will further narrow the income gap between urban and rural areas without significant. From the perspective of time, this reduction effect shows a "U-shaped" structure that decreases first and then increases; the advancement of urbanization will expand the net income gap between urban and rural properties, and the widening of the urban-rural wealth gap will further narrow the urban-rural income gap, which is not significant. From a time point of view, this shrinking effect appears an inverted U-shaped 
structure that increases first and then decreases; 3) The advancement of urbanization is conducive to shrink the transfer net income gap between urban and rural areas, and further reduce the income gap between urban and rural areas, which is relatively small. From the time point of view, it shows an "inverted U-shaped" structure that increases first and then shrinks. To sum up, urbanization is conducive to shrink the income gap between urban and rural areas with an "inverted U-shaped" structure that increases first and then shrinks.

Based on the above research findings, the following targeted and operational policy recommendations are proposed: 1) Multiple methods to increase the wage income of farmers. On the one hand, increase the training of migrant workers in vocational skills and legal knowledge to improve their working ability and work efficiency in the process of urbanization. On the other hand, gradually increase the various welfare benefits for rural migrant workers in cities to realize equal pay for equal work, and further narrow the wage income gap between urban and rural areas. 2) Increase the net income of farmers by multiple channels. The first is to increase investment in agricultural infrastructure, improve the system of agricultural support and protection, accelerate the process of agricultural modernization, and increase the income from agricultural operations. The second is to develop labor-intensive industries such as agricultural product processing, leisure agriculture and rural tourism, and rural service industries. Promote the integration of rural primary, secondary, and tertiary industries, and increase the non-agricultural income of rural residents. 3) Various measures to increase the net income of farmers' property. Net property income includes net interest income, dividend income, net income from savings insurance, net rental income from the transfer of contracted land management rights, net income from rental housing, net income from rental of other assets, and net rent from converted housing. For farmers, the net income from the transfer of contracted land management rights is the main channel for increasing net income at this stage. Therefore, we should continue to accelerate the registration of rural land contractual management rights, and grant farmers the right of possession, usage, income, circulation, contracting mortgage and guarantee for the contracted land. At the same time, it will further improve the land compensation and circulation mechanism and raise the income level of farmers in the process of urbanization. 4) Increase farmers' net income in multiple ways. The first is to further reduce the urban bias of central and local government fiscal expenditures, and further increase rural residents' old-age subsidies, medical subsidies and education subsidies etc. The second is to combine state relief with collective subsidies to form a new situation in which rural relief relies on national and collective of "walking on two legs" to further improve rural social security capabilities.

\section{Acknowledgements}

This work was sponsored by Sichuan Old Revolutionary Base Development Research Center. 


\section{References}

[1] Changjiu, F., Krugman, P., et al. (2011) Space Economics: Urban Regional and International Trade. Renmin University Press, Beijing, 156-189.

[2] Lin, Y.F. and Liu, M.X. (2003) China's Economic Growth Convergence and Income Distribution. World Economy, 8, 3-10.

[3] Yan, S.M. (2016) Study on the Relationship between Urbanization and Urban-Rural Income Gap: Based on Panel Data of 17 Prefectural Cities in Henan Province. Financial Theory \& Practice, 2, 46-52.

[4] Lewis, W.A. (1954) Economic Development with Unlimited Supplies of Labor. Development with Unlimited Supplies of Labor, 22, 139-191.

https://doi.org/10.1111/j.1467-9957.1954.tb00021.x

[5] Todaro, M.P. (1969) A Model of Labor Migration and Urban Unemployment in Less Developed Countries. American Economic Review, 59, 138-148.

[6] Lu, M. and Chen, Z. (2004) Urbanization, Urban-Oriented Economic Policies and Urban-Rural Income Gap. Economic Research, 4, 50-53.

[7] Yang, G.A. and Xu, Y. (2010) The Relationship between Urban-Rural Income Gap and Urbanization in Western China: A Case Study of Qinghai Province. Progress in Geography, No. 8, 961-967.

[8] Zhou, Y.B. (2009) Urbanization, the Gap between Urban and Rural Areas, and the Change in the Overall Income Gap of Residents Across the Country: An Empirical Test of the Inverted U-Hypothesis of the Income Gap. Quarterly Journal of Economics, 4, 1239-1256.

[9] Wang, M. and Cao, R.L. (2015) An Empirical Study on the Influence of Urbanization on the Urban and Rural Residents' Property Income Gap in China. Macroeconomic Research, 3, 76-84.

[10] Fang, N. and Zhang, K.H. (2015) Empirical Study on the Relationship between Urbanization and Farmers' Wage Income Based on ECM Model. Statistics and Decision, 10, 136-138.

[11] Ouyang, J.Q. and Wang, Y.P. (2014) The Impact of Urbanization on Narrowing the Urban-Rural Income Gap. Urban Problems, 6, 94-100.

[12] Wu, P., Li, J.Q. and Jing, Z.Z. (2016) Urban-Rural Income Gap and the Level of Urbanization: A Survey of Sources of Income Gap. Industrial Technology \& Economy, 8, 114-121.

[13] Zeng, G.A. and Hu, J.J. (2008) Reasons for the Formation and Expansion of the Income Gap between Urban and Rural Residents in China since 2000: An Analysis of the Source of Income. Finance and Trade Economics, 3, 53-55.

[14] Zuo, Y.H. (2012) Analysis of Income Gap between Provinces Cities and Town of China. Economic Problems, 1, 27-30.

[15] Li, Q.Y. and Chi, C. (2015) Overall Decomposition of Regional Difference of Income Gap between Urban and Rural Areas-Based on the Perspective of Income Source. Reform of the Economic System, 6, 47-54. 